\title{
The Influence of Financial Socialization, Financial Behavior, Locus of Control and Financial Stress on Young Adults' Financial Vulnerability
}

Mervin Anthony, Mohamad Fazli Sabri, Rusitha Wijekoon, Husniyah Abdul Rahim, Haslinda Abdullah, Mohd. Amim Othman \& Irwan Syah Md. Yusoff

To Link this Article: http://dx.doi.org/10.6007/IJARBSS/v11-i19/11738 DOI:10.6007/IJARBSS/v11-i19/11738

Received: 13 October 2021, Revised: 29 October 2021, Accepted: 21 November 2021

Published Online: 23 December 2021

In-Text Citation: (Anthony et al., 2021)

To Cite this Article: Anthony, M., Sabri, M. F., Wijekoon, R., Rahim, H. A., Abdullah, H., Othman, M. A., \& Yusoff, I. S. M. (2021). The Influence of Financial Socialization, Financial Behavior, Locus of Control and Financial Stress on Young Adults' Financial Vulnerability. International Journal of Academic Research in Business and Social Sciences, 11(19), 289-309.

Copyright: ( 92021 The Author(s)

Published by Human Resource Management Academic Research Society (www.hrmars.com)

This article is published under the Creative Commons Attribution (CC BY 4.0) license. Anyone may reproduce, distribute, translate and create derivative works of this article (for both commercial and non-commercial purposes), subject to full attribution to the original publication and authors. The full terms of this license may be seen

at: http://creativecommons.org/licences/by/4.0/legalcode

Special Issue Title: Youth and Community Wellness, 2021, Pg. 289 - 309

Full Terms \& Conditions of access and use can be found at http://hrmars.com/index.php/pages/detail/publication-ethics 


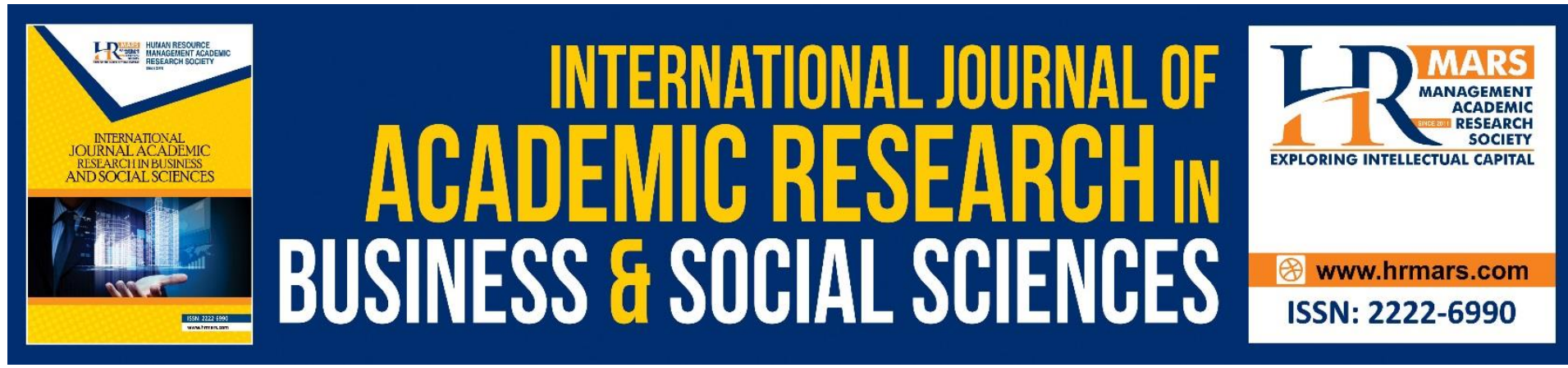

\title{
The Influence of Financial Socialization, Financial Behavior, Locus of Control and Financial Stress on Young Adults' Financial Vulnerability
}

\author{
Mervin Anthony², Mohamad Fazli Sabri ${ }^{1,2}$, Rusitha Wijekoon², \\ Husniyah Abdul Rahim², Haslinda Abdullah², Mohd. Amim \\ Othman² \& Irwan Syah Md. Yusoff ${ }^{2}$ \\ ${ }^{1}$ Institute for Social Science Studies, Universiti Putra Malaysia, 43400 UPM Serdang, \\ Selangor, Malaysia, ${ }^{2}$ Department of Resource Management \& Consumer Studies, Faculty of \\ Human Ecology, Universiti Putra Malaysia, 43400 UPM Serdang, Selangor.
}

Email: fazli@upm.edu.my

\begin{abstract}
The degree of Malaysian household debt remains high, at present among the highest in Asia, raising concerns about its sustainability. Based on that existing issue and results of the several studies the question is arisen regarding what needs to be done to address the high levels of financial vulnerability experienced by the Malaysians, especially the young adults. Therefore, major objective of the current study was to examine the major determinants that affect financial vulnerability, and allow policymakers to address the above issue. A multi stage random sampling method was performed to draw a representative sample of Malaysian young adults, and 651 duly filled responses were received through the self-administered questionnaire. As stated by the multiple regression results, $53.1 \%$ of the total variance of financial vulnerability was explained by the model. Determinants of financial vulnerability examined by this study comprise financial socialization, financial behavior, locus of control, and financial stress; all of them were significantly related with the financial vulnerability and except financial stress, all other three determinants were shown negative relationships. Therefore, current study has both the theoretical and practical contributions, and offers experts with actionable insights regarding the determinants of young adults' financial vulnerability when designing policies to prevent them from moving from a state of lower to higher financial vulnerability overtime.
\end{abstract}

Keywords: Financial Socialization, Financial Behavior, Locus of Control, Financial Stress, Financial Vulnerability

\section{Introduction}

Malaysians are confronting an elevated economic risk, with decreasing monetary security leaving numerous people financially vulnerable. Especially, a rising number of young adults are struggling financially, which is negatively accompanying with well-being in numerous areas of their life (Serido \& Deenanath, 2016). In terms of financial vulnerabilities, just about 
$33 \%$ of young adults are monetarily reliant on their guardians (FINRA IEF, 2013), and numerous live with their parents out of financial obligation (DeNavas-Walt \& Proctor, 2014). Moreover, many young adults lack basic financial skills and knowledge (Babiarz \& Robb, 2014). Finances are related with remarkable pressure for several young adults (American Psychological Association, 2018), and it is associated with increased physical health risks (Bemel et al., 2016), mental health risks (Eisenberg et al., 2001), and academic health risks (Kim, 2007). Hence, it is fundamental that we increase the financial well-being of young adults. This could be achieved via enhanced financial socialization (LeBaron et al., 2018). This is particularly timely given the present financial crisis because of COVID-19 associated restrictions, as previous studies suggest that the majority of the financially vulnerable young adults are frequently extremely affected by financial catastrophes (Kim et al., 2017). Furthermore, in case of a crisis, young adults attempt to diminish spending, and trying to adjust their financial plans better, which slows the economic regaining (Mian et al., 2013).

The current financial crisis due to COVID-19 pandemic plunged millions of people, especially young adults throughout the world into joblessness, savings deficit, and overindebtedness. Anxiety regarding the higher degrees of borrowing and low degrees of savings as sources of individuals' financial vulnerability has been the focal point of conversations and research amongst many policymakers and stakeholders. The monetary crisis left many young adults across the globe over-indebted and unemployed with little or no savings, as a result making them feel financially vulnerable. In reality, as indicated by a report by the Organization for Economic Cooperation and Development (OECD, 2020), late advancements, for example, the COVID-19 crisis have driven numerous young adults to now be psychologically and financially vulnerable, and deepened the current vulnerability of, for example, low-income young adults.

Generally, financial vulnerability is accompanying with struggle in supporting financial consumption and commitments, with the threat of default (Kim, 2016). This can convert into young adults' failure to service debt and meet their fundamental day-to-day requirements without trouble. According to the data, Malaysian households aggregated debt was $88.4 \%$ of the gross domestic product (GDP) (Central Bank of Malaysia, 2016). In addition, Malaysia is existing among the top 15 nations with the most elevated household debt, together with a cluster of developed economies. Even though, the degree of debt comparative with income gives some sign of the individuals' financial circumstance, the nature of debt matters; this features the capacity of households to support their debts.

Even though, some past studies concerning young adults' financial vulnerability distinguished some drivers of financial vulnerability and hinted at potential explanations behind being or becoming financially vulnerable, possible determinants of financial vulnerability are still not explained the phenomenon completely. Further, while academics point out the significance of investigating young adults' propensity to drift toward higher vulnerability (O'Connor et al., 2019), and policymakers have observed that vulnerability is "a fluid state" which could be "temporary, sporadic or permanent" (Financial Conduct Authority, 2015 , p. 7), research findings of significant determinants of young adults' financial vulnerability is still missing. Hence, the major aim of this study is to find out the important determinants that influence financial vulnerability of young adults in Malaysia, especially financial related factors; financial socialization, financial behavior, financial stress, and psychological factors, for example, locus of control. Further, unlike previous studies, current study examined these factors deeply, and measured them through the several items to represent all the aspects of the selected variables. Additionally, it was permitted authors to 
study what aspects of the main determinants contribute more to identify the actual effect of their impact on financial vulnerability. Therefore, all the items of individual variables were described separately. Thus, this study addressed this gap and is the first to utilized the determinants such as, financial socialization, locus of control, and financial stress as influencing factors on financial vulnerability.

The rest of the paper is organized as follows. We first present literature review about the financial vulnerability and its determinants. Afterward, we explain the methodology that was used to conduct the survey, and then we present the results and discussion. Finally, conclusion and implications for practice were presented.

\section{Literature Review}

\section{Financial Vulnerability}

Financial vulnerability is conceptualized as "a state of powerlessness or limited ability to engage effectively in the marketplace, arising from an interaction of individual characteristics (e.g. cognitive capacity), individual states (e.g. life transitions), and external conditions (e.g. discrimination)" (Baker et al., 2005, p. 131). It alludes to "individuals' subjective feelings (e.g., of distress, fear, worry, and concern) about being susceptible to financial hardship" (He et al., 2020 , p. 86). Usually, financially vulnerable individuals experience "month-to-month fragility" (Salisbury \& Zhao, 2019, p. 8), unable to meet even the basic expenditures, such as, paying groceries, rent, utilities and bills, and repaying debts (Brüggen et al., 2017).

Financial vulnerability also described as "the likelihood that an individual will experience financial hardship" (O'Connor et al., 2019, p. 425), and is driven by several other risk factors which were proved as important antecedents of financial vulnerability, for instance, low financial literacy, low income, high debt, or significant deviations in individual circumstances (Financial Conduct Authority, 2015; Poh \& Sabri, 2017). Financial vulnerability has also been described and conceptualized more explicitly concerning admittance to lowcost credit, resulting in individuals borrowing at incredibly high rates, which represents a threat to both the purchaser and the financial institution that is granting credit (Akseli, 2012). The term "financial vulnerability" subsequently alludes to perceived threats to the financial situation of either the individual consumer or the household and the way in which the individual feels ready to manage the possible threat.

\section{Financial Socalization}

Financial socialization is "a process of learning and advancing values, knowledge, norms, standards, attitudes, and behaviors that promote financial viability and individual well-being" (Danes, 1994, p. 45). It is not only connected with managing money; it incorporates the advancement of principles, attitudes, values, and norms that would support or hinder the improvement of financial capability among people as well as enhance the well-being.

The adults learned the consumer knowledge and behaviors in their childhood via the interaction with socialization agents, for example, parents, other family members, peers, schools, and religion, then practice these knowledge and behaviors in their adulthood (Drever et al., 2015). Previous literature showed that several financial socialization outcomes of young adults are embedded in the financial socialization procedures came across in childhood (Gudmunson et al., 2015). Jorgensen et al (2016) researched the effect of financial socialization on financial decision making and expressed that people who had more chances to observe and interact with financial socialization agents behave well in taking financial decisions, and therefore, less financially vulnerable. Moreover, Rea et al. further confirmed these findings in 2019. 


\section{Financial Behavior}

Financial behavior is "a pattern of action over time such as earning, saving, spending, and gifting" and includes "financial turning points and decision making" (Gudmunson \& Danes, 2011 , p. 650). It refers to human behavior's that are related to the management of money, and accompanying with the financial behaviors, such as earning, spending, borrowing, saving, and protecting (Xiao et al., 2008). These behaviors are especially related to the personal finances (Xiao et al., 2014).

Financial behavior is also considered as one of the elements prompting high financial satisfaction and financial well-being (Coşkuner, 2016; Sabri et al., 2020a). Further, Fei et al. (2020) and Sabri et al. (2020b) detected financial behavior as one of the significant negative determinants among the Malaysian young employees. In a study by Hayes and Finney (2013) have measured the influence of financial behavior on the household financial vulnerability in measuring individual general financial position such as, an experience of financial difficulties, and projection of future financial position. Therefore, a negative association was evidenced between financial behavior and financial vulnerability.

Locus of Control

Locus of control denotes to "the tendency to perceive outcomes in life as a result of one's own actions and thus being within one's own control (i.e., internal locus of control), as opposed to being determined by external factors, such as chance or powerful others (i.e., external locus of control)" (Keenan \& McBain, 1979, p. 280). Individuals who are having high internal locus of control regularly attempt to dominate their current circumstance, while those with high external locus of control frequently feel helpless because they perceive that outcomes in life are outside their own control (Keenan \& McBain, 1979). Locus of control was first depicted as a personality trait alluding to an individual's steady beliefs of personal efficacy (Rotter, 1966). Later, it has also been depicted as an adapting resource facilitating certain coping styles (Van den Brande et al., 2016).

Moreover, it has an effect on the behaviors as well as non-financial and financial preferences of the people (Kesavayuth et al., 2018). Locus of control is also linked to financial satisfaction (Sumarwan \& Hira, 1993). Jorgensen et al (2016) claimed internal locus of control is more applicable in the studies correlated to individual financial management. In their study, Van de Venter et al (2012) revealed that the locus of control was positively related to the financial risk tolerance. If an individual has a high financial risk tolerance, their financial vulnerability is less. Hence, the locus of control has negatively influenced the financial vulnerability.

Financial Stress

Financial stress refers to "the force exerted on economic agents by uncertainty and changing expectations of loss in financial markets and institutions" (Cardarelli et al., 2011, p. 81). According to Hakkio and Keeton (2009, p. 15), several signs are accompanying with the financial stress, for example, "increased uncertainty about fundamental value of assets, decreased willingness to hold risky assets, increased uncertainty about behavior of other investors, increased asymmetry of information, and decreased willingness to hold illiquid asset". Financial stress is measured with an index called the "Financial Stress Index" (FSI), where financial crises are declared as the extreme value of the scale.

Financial stress has been recognized as a solid indicator of both psychological and physical well-being, which is particularly pertinent to low-income households who fight with the realisms of monetary requirements consistently (Krameret al., 2019). It could be defined as "a state of arousal that negatively affects a person's ability to adapt to different needs that 
arise in their environment or from the absence of means that allow attainment of soughtafter ends" (Pearlin \& Bierman, 2013, p. 330). Besides, financial stress increases with anticipated monetary loss, with risk, or with uncertainty (Cardarelli et al., 2011), and cause financial vulnerability. Household's demands include financial obligations such as paying the rent and buying food; they also include things that indirectly require money, such as caring for a car and keeping one's house clean are often called day-to-day financial stressors (Reich \& Zautra, 1983), and if an individual is unable to fulfill these demands of a family cause financial stress which direct them towards financial vulnerability (Reich \& Zautra, 1983). Moreover, Huang et al.'s (2020) study was dedicated to exploring how financial stress correlates with financial vulnerability among older adults in China, Ghana, India, Russia and South Africa, and revealed that a positive relationship with financial stress and financial vulnerability. According to the above-discussed literature, the research framework constructed for the study is;

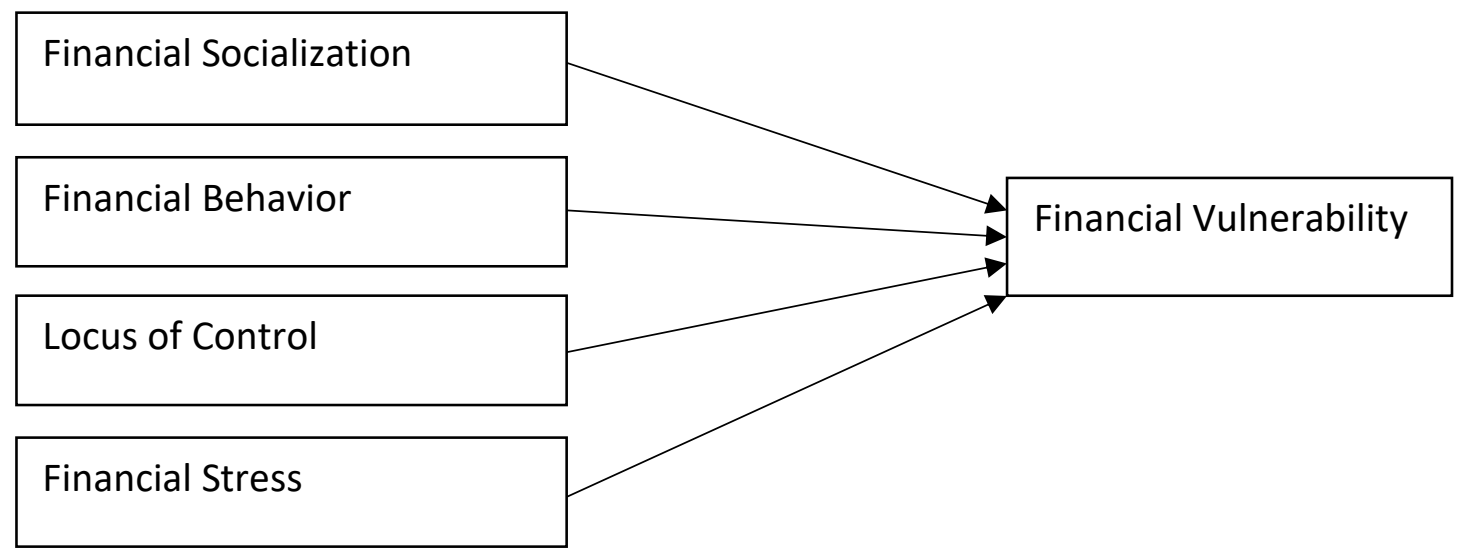

Figure 1: Research framework

Based on the available literature, and the research framework, accompanying hypotheses are;

$\mathrm{H}_{\mathrm{a} 1}$ : Financial socialization is linked negatively with financial vulnerability.

$\mathrm{H}_{\mathrm{a} 2}$ : Financial behavior is linked negatively with financial vulnerability.

$\mathrm{H}_{\mathrm{a} 3}$ : Locus of control is linked negatively with financial vulnerability.

$\mathrm{H}_{\mathrm{a} 4}$ : Financial stress is linked positively with financial vulnerability.

\section{Research Methodology}

Participants, Design, and Sampling

In the current study, a total of 750 Malaysian households who were in the age range of 18-40 were selected as respondents for the current study from five (5) zones in Malaysia (i.e. Central, Southern, Northern, Eastern, and East Malaysia) utilizing the multi-stage random sampling method, and therefore, 150 respondents were targeted from each zone mentioned above. A team of well-trained enumerators was engaged in the data collection process, and a structured questionnaire with open-ended and non-open ended items was used. After the discussion of the households, only the respondents who were ranged within the defined age category were selected for the survey. A series of pre-tests were completed to guarantee the validity, and reliability of the questionnaire, and the questionnaire items were revealed reliable and valid. Therefore, the questionnaire, which was used in pre-tests, was directly utilized to the final data collection process without any change. Because of final survey 651 duly completed questionnaires were received, and subjected to the data analysis. Descriptive 
analysis and multiple linear regression statistics were performed with SPSS version 26 . The demographic details of the respondents of the current study are given in the Table 1.

Table 1 : Demographics of the respondents

\begin{tabular}{lll}
\hline Variable & $\mathbf{n}$ & $\mathbf{\%}$ \\
\hline Gender & & \\
Male & 198 & 30.4 \\
Female & 453 & 69.6 \\
Age & & \\
$<20$ & 23 & 3.5 \\
$20-25$ & 400 & 61.4 \\
$26-30$ & 68 & 10.4 \\
$31-35$ & 78 & 12 \\
$36-40$ & 82 & 12.6 \\
Ethnicity & & \\
Malay & 530 & 81.4 \\
Chinese & 62 & 9.5 \\
Indian & 28 & 4.3 \\
Others & 31 & 4.8 \\
Marriage Status & & \\
Single & 487 & 74.8 \\
Married & 151 & 23.2 \\
Divorced & 10 & 1.5 \\
Widowed & 3 & 0.5 \\
Highest Educational Level & & \\
No formal education & 2 & 0.3 \\
Secondary School & 72 & 11.1 \\
Tertiary Education & 560 & 86 \\
\hline & & \\
\hline & & \\
\hline
\end{tabular}

Out of 651 respondents, number of female respondents was doubled (69.6\%) than that of male respondents (30.4\%). The participated respondents were categorized in to five groups according to their age, and the lowest number of respondents was noted in the age category below 20 years (3.5\%), while highest number of young adults was recorded in the age group between 20 and 25 years (61.4\%). Most of the respondents were single $(74.8 \%)$, and the highest number of respondents were Malay (81.4\%), followed by Chinese $(9.5 \%)$ and Indians (4.3\%). In terms of education level, $86.0 \%$ was completed their tertiary education.

\section{Variables Measurement}

Respondent's financial socialization measurement was assessed using Manfrè (2017) and Lanz et al.'s (2019) financial socialization items. The construct was consisted of ten items with five-point Likert scale which was ranged from (1) strongly disagree to (5) strongly agree. Respondent's financial behavior measurement was assessed using Kim (2004), and Ismail et al.'s (2017) financial behavioral scales. In all, it consists of ten items with five measurement scale (1-strongly disagree to 5-strongly agree).

Locus of control measurement of the respondents was assessed using Van Daalen et al.'s (1989) perceived locus of control scale. It contains 19 questions with five point Likert measurement scale which was ranged (1) strongly disagree to (5) strongly agree. Young adults 
were asked to answer if they were come across eight circumstances that pointed out their financial stress where statements were from Delafrooz and Paim (2013); Lim et al (2014). Mean score was used in order to determine financial stress of the respondents on a scale of " 1 " was the lowest score of finical stress (strongly disagree) and the scale " 5 " was the highest score of financial stress (strongly agree). Respondent's financial vulnerability measurement was assessed using Anderloni et al.'s scale (2012), which was consisted of ten items with fivepoint measurement scale (1-strongly disagree to 5-strongly agree).

\section{Results and Discussion}

Table 2 outlined the socio-economic profile of the respondents. Most of the respondents (53.5\%) were students, and $29.8 \%$ were government and private sector employees. Only $10.4 \%$ was recorded under the category of unemployed. It is surprising to see more than fifty percent $(57.6 \%)$ of the respondents did not have any income, while $5 \%$ of them had more than 7,101 RM monthly income. When considering the monthly income of the spouse, majority of them had $<\mathrm{RM} 2,500$, and $3.4 \%$ income was $>\mathrm{RM} 7,101$.

Table 2: Socio-economic characteristics of the respondents

\begin{tabular}{lll}
\hline Variable & $\mathbf{n}$ & $\mathbf{\%}$ \\
\hline Employment & & \\
Unemployed & 68 & 10.4 \\
Civil/Goverment Servant & 113 & 17.4 \\
Private Sector Employee & 81 & 12.4 \\
Self Employed & 27 & 4.1 \\
Student & 348 & 53.5 \\
Others & 14 & 2.2 \\
Monthly Income & & \\
No Income & 375 & 57.6 \\
< RM2,500 & 98 & 15.1 \\
RM2,501-RM3,170 & 46 & 7.1 \\
RM3,171-RM3,970 & 27 & 4.1 \\
RM3,971-RM4,850 & 24 & 3.7 \\
RM4,851-RM5,880 & 26 & 4.0 \\
RM5,881-RM7,100 & 23 & 3.5 \\
>RM7,101 & 32 & 5.0 \\
Spouse Monthly Income & & \\
No Income & 9 & 1.4 \\
< RM2,500 & 40 & 6.1 \\
RM2,501-RM3,170 & 17 & 2.6 \\
RM3,171-RM3,970 & 22 & 3.4 \\
RM3,971-RM4,850 & 15 & 2.3 \\
RM4,851-RM5,880 & 14 & 2.2 \\
RM5,881-RM7,100 & 12 & 1.8 \\
> RM7,101 & 22 & 3.4 \\
\hline
\end{tabular}

Financial Socialization

The mean scores of the financial socialization statements are given in the Table 3. Based on the results, higher mean score shows respondent's positive financial socialization for the 
particular behavior in personal finance, savings and financial attitude in managing financial management whereas lower mean score shows their less agreeableness.

Results showed that respondents have been taught since childhood by their parents about the importance of saving, and how to be a smart consumer have more positive influence on young adults managing money. Nevertheless, it also showed that the respondents were less agreed when they were enquired about their parents taught on how to use credit cards facility accordingly, how their parents discussed how to obtain a good credit assessment, and lastly on how they were discussed finances with their family. Past study revealed that students' financial behavior was governed by childhood financial knowledge, consumer experience, savings, and expenditure pattern (Sabri \& MacDonald, 2010). Moreover, Mitchell et al (2006) added that education level can impact one's saving behavior too. Sadiq et al (2014) disclosed that education level, investment knowledge, income level, and investment experience influence the investor's financial behavior of risk tolerance.

Lusardi and Mitchell (2009) also revealed that higher self-confidence and financial literacy in financial knowledge increase the likelihood of retirement planning, and the importance of financial education was highlighted through this finding. Financial education will prepare people with the fundamental financial knowledge and boost the people's selfconfidence in dealing with financial decisions.

Table 3: Respondents' financial socialization

\section{Statement}

1. My parents have discussed family finances with me.

2. My parents have told me about the importance of saving.

3. My parents have taught me how to be a smart consumer.

4. My parents have taught me how to use credit cards facilty accordingly.

5. My parents and I have discussed how to obtain a good credit assessment.

6. My parents have discussed how to fund university / college education fees with me.

7. I make financial decisions based on what my parents have done in a similar situation.

8. In financial management, I look at my parents as my role model.

9. My parents became role models for me on how to manage financial matters.

10. My parents have a positive influence on me on managing money.
Mean

4.35

3.39

3.59

4.05

4.17

\section{Financial Behavior}

The mean scores of the financial behavior statements are given in the Table 4. Based on the results, higher mean score shows respondent's positive financial behavior for the particular behavior in personal finance whereas lower mean score shows their less agreeableness. Results showed that the respondents were more unified stating that they have long-term financial goals and strive to achieve the goals, regularly check the price of the goods carefully before buying any products, making savings to meet personal or family financial goals, and spend accordingly to their weekly or monthly budget. Nevertheless, it shows that the respondents were less agreed when they were enquired about their behavior in paying loan installment, making minumum payment for loan taken, and tracking their money spending. 
Less perceived financial wellness was reported among the consumers who exhibits greater frequency of negative financial behaviors (e.g. late in paying bills) (O'Neill et al., 2005). In fact, Xiao (2009); Joo (2008); Garman and Forgue (2006); Joo and Grable (2004) and Parrotta and Johnson (1998) declared that financial behavior is the major influencing factor of one's financial status of satisfaction.

Table 4: Respondents' financial behavior

\section{Statment}

1. I spend according to my weekly or monthly budget.

2. I keep track of where my money is spent.

3. I set aside money for emergency expenses.

4. I save to meet personal / family financial goals.

5. I keep the purchase receipt.

6. I make the minimum payment for a loan taken.

7. I record my loan installment payment.

8. I am late in paying my loan installment

9. I check the price of the goods carefully before buying them.

10. I have long-term financial goals and strive to achieve them.

\section{Mean}
4.05
3.46
3.94
4.18
3.55
3.31
3.49
2.31
4.33
4.34

\section{Locus of Control}

Table 5 displays the mean scores of the statements which were used under the construct of locus of control. Based on the results, higher mean score indicates the degree of agreeableness towards the locus of control of the respondents on the particular dimension while lower mean score indicates less agreeableness. Results showed that the respondents were more agreed that whether they become rich or poor depends on their own abilities, savings and investments are the key to wealth accumulation and their life is determined by their abilities and actions.

Nonetheless, findings showed that the respondents were less agreed when they were asked about "there was nothing that a person can do to avoid poverty", "only those who inherit property or win cash prizes can become rich", and "they think their finances are mostly determined by others".

It can be concluded that the respondents feel that whenever they become rich or poor depends on their own abilities. Many times they have little influence over things that had happened to them which reflects the highest average score (mean $=4.37$ ). Ganster and Fusilier (1989) stated that the locus of control was one of the significant determinant of wellbeing. Later, Spector et al (2002) added that locus of control as a universal component of wellbeing. Hence, an individual general beliefs in their personal control in life are essential. So, respondents believed that outsides forces (externality) have influence their personal control in life which also impacted on their financial well-being.

The second highest score was about respondents feel that "savings and investments are the key to wealth accumulation" (mean $=4.32$ ). Concurrently, the third highest score was about respondents feel about "my life is determined by my abilities and actions" (mean = 4.16). Statement that stating "there is nothing that a person can do to avoid poverty" was received the lowest average score of 2.29. This finding entailed that respondents feel they do not have control over their financial situation. This indicated that respondents' low stability 
in believing in themselves (internal locus of control) would influence their financial well-being. As a result, respondents do not feel confident in their financial well-being. According to Weisz et al (1984) this is due to collectivist characteristics that are more emphasized on the secondary control.

Table 5: Respondents' locus of control

\section{Statement}

Mean
4.32
4.37
3.60
3.15
2.29
2.45
4.14
3.06
2.95
3.80
2.96

3.22

3.34

3.07

3.91

4.07

4.16

3.01

2.36

\section{Financial Stress}

Table 6 shows the analysis of financial stress that faced by the respondents based on mean scores. The statement "I worry if I am late paying the bills" indicated the highest percentage (4.16) among the responses. Second highest score was received the statement "I could not sleep because I was worried about paying the bills" (3.25). Meanwhile, the third highest score was exhibited by the depression and restless feelings with their current financial situation (3.22).

From the results, it was reported that worry in delay in paying bills, could not sleep because worried about paying the bills, and worried about current financial situation were among the most frequent situations that were experienced by the young adults for the past six months. Overdue payment can lead to interest charges and penalties. This may lead to money issues because people need to balance their finances and put them on the edge. The results also demonstrated that respondents felt worried and had less sleep because of concerned about paying their billing costs.

At this moment, with the increasing standard of living as well as the fast pace Malaysia's development make individual to easily fall sick either from the mild disease (i.e. 
influenza) up to chronic disease (i.e. diabetes). Even though, health care was told to be exempted from the Goods and Service Tax (GST), but in reality not all of the heath care product particularly medications in the private sectors are to be exempted. In line with that, Health Tracking Household Survey (HTHS) in 2010 (Carlson et al., 2012) divulged many respondents faced problems in paying off medical bills and some of them even have outstanding debt due to high medical bills.

Moreover, results found that respondents felt apprehensive regarding their current financial situation. With the new implementation of the Goods and Service Tax (GST) since April $1^{\text {st }} 2015$, people tend to be meticulous with their money. Not to mention that respondents have long term commitments in family development. So, Mills and Blossfeld (2005) said that it become a new challenge which requires a lot of commitments. The fluctuating price of goods, services and fuel also become worsen for them to survive (Cooley \& Quadrini, 2006).

Employees who are experiencing high level of financial stress has the inclination to manage their financial issues, and spend time at their workplace by being upset on their personal finances instead of being productive. Due to the anxieties on personal finances might hinder their work as they might spend time of their paid working hour to discuss with their colleagues regarding their personal financial problems and settle their personal bills during the working hours. Under this circumstances, they were frequently reported to be inefficient and incompetent. It can be seen that financial stress not only convey negative consequences to the employees, but to their employers and their families (Employee Financial Wellness Survey, PwC, 2016).

Table 6: Respondents' financial stress

Statement

Mean

1. I worry if I am late paying the bills.

4.16

2. I could not sleep because I was worried about paying the bills.

3.25

3. I get depressed and restless with my current financial situation.

4. I can not afford (financially) to see a doctor when I am sick.

2.20

5. I cannot afford (financially) to get healthier food.

2.31

6. I have high blood pressure due to financial difficulties.

1.95

7. I am worried about medical expenses.

2.60

8. I became depressed as a result of thinking about financial matters.

2.66

Financial Vulnerability

The mean scores of the financial vulnerability statements are given in the Table 7. According to the results, higher mean score indicates the degree of agreeableness towards the financial vulnerability of the respondents on the particular situation, whilst lower mean score indicates less agreeableness. The findings showed that the respondents tend to agree that in the last six months, they were in a situation where the income that they received is not enough (3.11), they can't make savings every month (2.98), and the job they were involved in does not provide a stable income (2.82). 
However, the respondents were less agreed when they were asked about the statement "I borrow money from unlicensed money lenders" (1.57), "I have an outstanding monthly loan" (1.91), and "I borrow to buy daily necessities (basic necessities)" (1.94).

According to the past studies financial vulnerability is not necessarily related to having high debt. Households might also be stated as stressed or vulnerable when they are unable to do what they want, for example, going out for a meal with family and friends, taking a vacation, or enjoying hobbies and leisure activities (Worthington, 2006). Households, especially low-income households are also considered vulnerable and fragile if they are unable to make ends meet and pay their monthly expenses or have outstanding utility bills (Bridges \& Disney, 2004).

Regardless of whether the vulnerability is due to high debt or non-debt commitments, households might be vulnerable to adverse shocks due to the changing environment, for example, fluctuations in interest rates, changes in income or GDP, changes in asset prices, for instance, housing, or sudden unemployment (Kim et al., 2016). Further, vulnerable households usually experience with the deprivation (Narayan et al., 2000), which might result in low productivity levels in the workplace, financial exclusion, and absenteeism.

\section{Table 7: Respondents' financial vulnerability}

\begin{tabular}{lc}
\hline Statement (In the last 6 months........) & Mean \\
\hline 1. I can't make savings every month. & 2.98 \\
2. I do not have cash for emergencies. & 2.64 \\
3. The income I receive is not enough. & 3.11 \\
4. The job I am involved in does not provide a stable income. & 2.82 \\
5. I could not concentrate on work due to financial problems. & 2.59 \\
6. I depend on side jobs or overtime to finance the cost of living. & 2.80 \\
7. I borrow to buy daily necessities (basic necessities). & 1.94 \\
8. I borrow money from unlicensed money lenders. & 1.57 \\
9. I have an outstanding monthly loan. & 1.91 \\
10. I cant afford to spend money during the end of the month because I run out of & 2.27 \\
\hline
\end{tabular}

The multicollinearity for the determinants of this study is shown below in Table 8. All the determinants have a tolerance value of 0.2 and above. It implies that there is no multicollinearity among the predictors since the tolerance value is close to one. Also, all the predictors have a VIF value below five. It implies there is no existence of multicollinearity among the predictors because VIF is not a long way from one. The results displayed that the condition of proving is met and there is no correlation within the predictors. Therefore, multiple regression analysis could be performed.

Table 8: Tolerance and VIF Value

\begin{tabular}{lcc}
\hline Variables & Tolerance & Variance Inflation Factor (VIF) \\
\hline Financial Socialization & .791 & 1.264 \\
Financial Behavior & .864 & 1.157 \\
Locus of Control & .696 & 1.437 \\
Financial Stress & .792 & 1.263 \\
\hline
\end{tabular}

The Table 9 displays the multiple regression results of the four factors of the study, and explained $53.1 \%$ of the variance of the financial vulnerability, and the rest of the variance 
would be clarified by the different other elements which were not used in the study. The beta values demonstrate the percentage of involvement of independent variables to describe the dependent variable, and the significant value may describe whether the effect of independent variables are significant or not when predicting the dependent variable. All four independent variables; financial socialization, financial behavior, locus of control, and financial stress were significant, hence, the hypotheses $\mathrm{H}_{\mathrm{a} 1}, \mathrm{H}_{\mathrm{a} 2}, \mathrm{H}_{\mathrm{a} 3}$ and $\mathrm{H}_{\mathrm{a} 4}$ were accepted. The variable, financial stress was the highest predictor of financial vulnerability of the Malaysian young adults (beta= 0.673).

According to the results, financial socialization, financial behavior, and locus of control were negatively predicted the financial vulnerability, and meanwhile, only financial stress was positively predicted the financial vulnerability. Furthermore, young adults with greater level of financial socialization, financial behavior, and locus of control have shown less financial vulnerability, conversely with higher financial stress level, a higher level of financial vulnerability was observed.

Moreover, positive financial socialization and financial behavior may support young adults to succeed their financial status via budgeting, and intensifying their determinations to earn better earnings, and secure their upcoming financial requirements. Based on the beta values, locus of control was become the second greatest predictor on financial vulnerability, and followed by financial behavior, and financial socialization.

Table 9: Multiple regression results of the determinants of vulnerability

\begin{tabular}{lllll}
\hline Variable & b & Beta & t & Sig. \\
\hline Financial Socialization & -0.063 & -0.053 & -1.691 & $0.02^{*}$ \\
Financial Behavior & -0.085 & -0.058 & -1.856 & $0.02^{*}$ \\
Locus of Control & -0.573 & -0.203 & -4.568 & $0.003^{* *}$ \\
Financial Stress & 0.935 & 0.673 & 21.960 & $0.000^{* *}$ \\
\hline
\end{tabular}

$\mathrm{R}=.731 ; \mathrm{R}^{2}=.534 ;$ Adjusted $\mathrm{R}^{2}=.531 ; \mathrm{F}=184.587 ;$ Sig. $\mathrm{F}=.000$

${ }^{*} p<.01$

$* * p<.001$

\section{Conclusion}

In conclusion, a negative significant association was revealed between financial socialization, financial behavior, and locus of control towards financial vulnerability of Malaysian young adults, while a positive significant association was revealed between financial stress and financial vulnerability. The result also indicated that the financial socialization, financial behavior, locus of control, and financial stress are significant determinants of young adults' financial vulnerability and the $53.1 \%$ of the variance in financial vulnerability was explained by the regression model.

\section{Implications, limitations and Future Research}

As a practical implication, we offer policymakers and other practitioners actionable insights regarding the determinants of financial vulnerability of Malaysian young adults. Especially, these stakeholders and policy makers can get a lot of traction from concentrating on the vital characteristics of vulnerable young adults - for example, their financial socialization, financial behavior, locus of control, and financial stress- when formulating policies to prevent them from becoming or staying "trapped" in the state increased financial vulnerability. 
Financial vulnerability may frequently happen intensely due to the unpredicted income shocks - for example, COVID-19 crisis - it is significant at such times that we help people feel capable to mentally overcome these financially stressful events, which needs to have sufficient financial socialization, and proper financial behavior. Therefore, governmental and non-governmental sponsored financial education, and counselling programs might be an ideal solution for the future in order to increase the Malaysian young adults' financial socialization, and financial behavior to reduce their financial vulnerability. According to the findings of Sabri and Wijekoon (2019), the promising results might be expected when designing those programs by giving special attention on young adults' gender and the ethnicity. Moreover, it is important to financially socialize the young children with the help of simple tools, for example, money kits to familiarize them on financial matters (Sabri et al., 2019) in order to reduce their financial vulnerability when they become to young adults. Moreover, the financial behavior enhancing programs, for instance, group workshops on proper financial practices or individual programs between financial counsellors, and working young adults, might help them effectively. It might be compelling in encouraging economic well-being in Malaysian young adults by reducing their financial vulnerabilities. Furthermore, decreased financial stress might assist them to be more focused on their studies to achieve higher results, and work environment to increase their productivity, thus benefiting the employers.

As usual, we have identified some limitations which are associated with our work, which offer promising avenues for future studies. Our data collection was straddled the COVID-19 pandemic period, which was identified as a period having more financial and psychological pressure. It might be ideal to study the determinants of young adults' financial vulnerability during less stressful times as well. Even though, the sample was drawn to represent the population, the size of the sample was $N=651$. Future studies would be ideal to carry out with larger sample sizes. Moreover, future studies would include additional factors to reveal the mental nuances of financial vulnerability.

\section{Acknowledgments}

This study was funded by the Geran Putra Universiti Putra Malaysia (UPM/800/2/2/4-Geran Putra - The Influence of Personal Finance and Psychological Factors on Financial Health among Malaysian Millennial Youth).

\section{References}

Abdullah, N., Fazli, S. M., \& Arif, A. M. M. (2019). The Relationship between attitude towards money, financial literacy and debt management with young worker's financial wellbeing. Pertanika Journal of Social Sciences and Humanities, 27(1), 361-387.

Akseli, O. (2012). Vulnerability and access to low cost credit. In: Devenney, J. \& Kenny, M. (Eds), Consumer Credit, Debt and Investment in Europe. Cambridge: Cambridge University Press.

American Psychological Association. (2018). Stress in America: Generation Z. stress in America TM survey. Retrieved on 5/07/2021 from https ://www.apa.org/news/press/releases/ stress/2018/stress-gen-z.pdf.

Anderloni, L., \& Vandone, D. (2011). Risk of over-indebtedness and behavioral factors. In: Risk tolerance in financial decision making. Palgrave Macmillan: London.

Anderloni, L., Bacchiocchi, E., \& Vandone, D. (2012). Household financial vulnerability: An empirical analysis. Research in Economics, 66(3), 284-296. 
Babiarz, P., \& Robb, C. A. (2014). Financial literacy and emergency saving. Journal of Family and Economic Issues, 35(1), 40-50. https://doi.org/10.1007/s10834-013-9369-9.

Baker, S. M., Gentry, J. W., \& Rittenburg, T. L. (2005). Building understanding of the domain of consumer vulnerability. Journal of Macromarketing, 25(2), 128-139.

Bemel, J. E., Brower, C., Chischillie, A., \& Shepherd, J. (2016). The impact of college student fnancial health on other dimensions of health. American Journal of Health Promotion, 30(4), 224-230. https://doi.org/10.1177/0890117116639562.

Boonsiritomachai, W., \& Pitchayadejanant, K. (2019). Determinants affecting mobile banking adoption by generation $Y$ based on the Unified Theory of Acceptance and Use of Technology Model modified by the Technology Acceptance Model concept. Kasetsart Journal of Social Sciences, 40(2), 349-358.

Bridges, S., and R. Disney. (2004). Use of credit and arrears on debt among low-income families in the United Kingdom. Fiscal Studies, 25,1-25.

http://dx.doi.org/10.1111/fisc.2004.

Brüggen, E., Hogreve, J., Holmlund, M., Kabadayi, S., \& Lofgren, M. (2017). Financial wellbeing: A conceptualization and research agenda. Journal of Business Research, 79, 228237. https://doi.org/10.1016/j.jbusres.2017.03.013

Cardarelli, R., Elekdag, S., \& Lall, S. (2011). Financial stress and economic contractions. Journal of Financial Stability, 7(2), 78-97.

Carlson, B. L., Hall, J., CyBulski, K., \& Strouse, R. (2012). Health Tracking Household Survey Methodology Report 2010 (Round Six). Center for Studying Health System Change.

Central Bank of Malaysia. (2016). Bank Negara Annual Report 2016. Central Bank of Malaysia, Kuala Lumpur. CFPB Financial Well-Being Scale: Scale Development Technical Report. Retrieved on 25/06/2021 from http://www.sjdm.org/dmidi/files/CFPB_Financial_Well Being_Scale_Technical_Report.pdf

Cooley, T. F., \& Quadrini, V. (2006). Monetary policy and the financial decisions of firms. Economic Theory, 27, 243-270

Coşkuner S. (2016). Understanding factors affecting financial satisfaction: The influence of financial behavior, financial knowledge and demographics. Imperial Journal of Interdisciplinary Research, 2(5), 377-385.

Danes, S. M. (1994). Parental perceptions of children's financial socialization. Journal of Financial Counseling and Planning, 5, 27-146.

Daud, S. N. M., Marzuki, A., Ahmad, N., \& Kefeli, Z. (2019). Financial vulnerability and its determinants: Survey evidence from Malaysian households. Emerging Markets Finance and Trade, 55(9), 1991-2003. https://doi.org/10.1080/1540496X.2018.1511421

De Sena Abrahão, R., Moriguchi, S. N., \& Andrade, D. F. (2016). Intention of adoption of mobile payment: An analysis in the light of the Unified Theory of Acceptance and Use of Technology (UTAUT). RAI Revista de Administração e Inovação, 13(3), 221-230.

Delafrooz, N., \& Paim, L. H. (2013). Role of financial stress on relationship between financial problem and financial wellness among Malaysia workers. African Journal of Business Management, 7(20), 1966-1972.

DeNavas-Walt, C., \& Proctor, B. D. (2014). Income and poverty in the United States: 2013. US Government Printing Office.

DeVaney, S. A. (1994). e usefulness of financial ratios as predictors of household insolvency: Two perspectives. Journal of Financial Counseling and Planning, 5, 5-24.

Drever, A. I., Odders-White, E., Kalish, C. W., Else-Quest, N. M., Hoagland, E. M., \& Nelms, E. N. (2015). Foundations of financial well-being: insights into the role of executive 
function, financial socialization, and experience-based learning in childhood and youth. Journal of Consumer Affairs, 49, 13-38. http://dx.doi.org/ 10.1111/joca.12068.

Eisenberg, N., Losoya, S., Fabes, R. A., Guthrie, I. K., Reiser, M., Murphy, B., Shepard, S. A., Poulin, R., \& Padgett, S. J. (2001). Parental socialization of children's dysregulated expression of emotion and externalizing problems. Journal of Family Psychology, 15, 183-205. https://doi.org/10.1037/0893-3200.15.2.183.

Employee Financial Wellness Survey. (2016). Retrieved on 5/07/2021 from https://assets. ctfassets.net/vv3ti973ux47/5x6tzTTytSPOJMLVDFNRLL/6899f0e70e2a16d4f085ed76b e683c1e/pwc-2016-employee-wellness-survey.pdf.

Fei, C. K., Sabri, M. F., Mohamed, N. A., Wijekoon, R., \& Majid A. Z. A. (2020). Determinants of financial vulnerability among young employees in Malaysia. Journal of Critical Reviews, 7 (15), 3097-3107. http://dx.doi.org/10.31838/jcr.07.15.425.

Financial Conduct Authority. (2015), Consumer vulnerability, Retrieved on 25/06/2021 from www.fca.org.uk/publications/occasional-papers/occasional-paper-no-8-consumervulnerability.

FINRA IEF. (2013). Financial capability in the United States: Report of financial capability in the United States.

http://www.usfnancialcapability.org/downloads/NFCS_2012_Report_Natl_Findings.pd f.

Ganster, D. G., \& Fusilier, M. R. (1989). Control in the workplace. In: C. L. Gooper \& I. T. Robertson (Eds.), International review of industrial and organizational psychology. Ghichester, England: Wiley. 235-280.

Garman, E., \& Forgue, R. (1997). Personal Finance. Boston, MA: Houghton Mifflin Company.

Greninger, S. A., Hampton, V.L., Kitt, K. A., \& Achacoso, J. A. (1996). Ratios and benchmarks for measuring financial well-being of families and individuals. Financial Services Review, 5(1), 57-70.

Gudmunson, C. G., \& Danes, S. M. (2011). Family financial socialization: Theory and critical review. Journal of family and economic issues, 32(4), 644-667.

Gudmunson, C. G., Zuiker, V. S., Katras, M. J., \& Sabri, M. F. (2015). Enhancing personal and family finance courses using case studies. College Student Journal, 49(3), 321-330.

Hakkio, C. S., \& Keeton, W. R. (2009). Financial stress: What is it, how can it be measured, and why does it matter. Economic Review, 94(2), 5-50.

Hanna, S., \& Wang, H. (1995). The adequacy of emergency funds to cover household expenditures. Consumer Interests Annual, 41, 224-225.

Hayes, D. A., \& Finney, A. D. (2013). The Genworth Index (volume 5): Measuring Consumer Financial Security and Vulnerability.

He, T., Derfler-Rozin, R., \& Pitesa, M. (2020). Financial vulnerability and the reproduction of disadvantage in economic exchanges. Journal of Applied Psychology, 105(1), 80-96. https://psycnet.apa.org/doi/10.1037/apl0000427

Huang, R., Ghose, B., \& Tang, S. (2020). Effect of financial stress on self-reported health and quality of life among older adults in five developing countries: a cross sectional analysis of WHO-SAGE survey. BMC geriatrics, 20(1), 1-12. https://doi.org/10.1186/s12877020-01687-5

Ismail, S., Faique, F. A., Bakri, M. H., Zain, Z. M., Idris, N. H., Yazid, Z. A., ... \& Taib, N. M. (2017). The role of financial self-efficacy scale in predicting financial behavior. Advanced Science Letters, 23(5), 4635-4639.

Johnson, D. P., \& Widdows, R. (1985). Emergency fund levels of households. In: K.P. 
Schnittgrund (Ed.), Proceedings of the 31st Annual Conference of the American Council of Consumer Interests (pp. 235-241). Fort Worth, TX: American Council Consumer Interest.

Joo, S. H., Durband, D. B., \& Grable, J. E. (2008). The academic impact of financial stress on college students. Journal of College Student Retention: Research, Theory and Practice, 10(3), 287-305.

Joo, S., \& Grable, J. E. (2004). An exploratory framework of the determinants of financial satisfaction. Journal of Family and Issues, 25(1), 25-50.

Jorgensen, B. L., Rappleyea, D. L., Schweichler, J. T., Fang, X., \& Moran, M. E. (2016). The financial behavior of emerging adults: a family financial socialization approach. Journal of Family and Economic Issues, 38, 57-69. http://dx.doi.org/ 10.1007/s10834-0159481-0

Keenan, A., \& McBain, G. D. M. (1979). Effects of type a behavior, intolerance of ambiguity, and locus of control on the relationship between role stress and work-related outcomes. Journal of Occupational Psychology, 52, 277-285. http://dx.doi.org/ 10.1111/j.2044- 8325.1979

Kesavayuth, D., Ko, K. M., \& Zikos, V. (2018). Locus of control and financial risk attitudes. Economic Modelling, 72, 122-131. http://dx.doi.org/ 10.1016/j.econmod.2018.01.010

Kim, D. (2007). The effect of loans on students' degree attainment: Differences by student and institutional characteristics. Harvard Educational Review, 77, 64-100. https://doi.org/ 10.17763/haer.77.1.n14t69l0q8292784.

Kim, J. (2004). Impact of a workplace financial education program on financial attitude, financial behavior, financial well-being, and financial knowledge. In: Proceedings of the association for Financial Counseling and Planning Education (Vol. 22, No. 1, pp. 82-89).

Kim, K., Wilmarth, M., \& Henager, R. (2017). Poverty levels and debt indicators among lowincome households before and after the great recession. Journal of Financial Counseling and Planning, 28(2), 196-212. https://doi.org/10.1891/1052-3073.28.2.196.

Kim, Y. I., Kim, H. C., \& Yoo. J. H. (2016). Household over-indebtedness and financial vulnerability in Korea: Evidence from credit bureau data. KDI Journal of Economic Policy, 38, 53-77. http://dx.doi.org/10.23895/kdijep.2016.38.3.53

Kramer, K. Z., Andrade, F. C. D., Greenlee, A. J., Mendenhall, R., Bellisle, D., \& Blanks, R. L. (2019). Periodic Earned Income Tax Credit (EITC) payment, financial stress and wellbeing: a longitudinal study. Journal of Family and Economic Issues, 40(3), 511-523.

Lanz, M., Sorgente, A., \& Danes, S. M. (2019). Implicit family financial socialization and emerging adults' financial well-being: A multi-informant approach. Emerging Adulthood, 2167696819876752.

LeBaron, A. B., Hill, E. J., Rosa, C. M., Spencer, T. J., Marks, L. D., \& Powell, J. T. (2018). I wish: Multigenerational regrets and reflections on teaching children about money. Journal of Family and Economic Issues, 39(2), 220-232. https://doi.org/10.1007/ s10834-0179556-1

Lee, D. K. C., \& Teo, G. S. Z. J. (2015). Emergence of FinTech and the LASIC Principles. Journal of Financial Perspectives, 3(3), 1.

Lim, H., Heckman, S., Montalto, C. P., \& Letkiewicz, J. (2014). Financial stress, self-efficacy, and financial help-seeking behavior of college students. Journal of Financial Counseling and Planning, 25(2), 148-160.

Lusardi, A., Mitchell, O. S., \& Curto, V. (2010). Financial literacy among the young. Journal of Consumer Affairs, 44(2), 358-380. 
Manfrè, M. (2017). Saving Behavior: Financial socialization and self-control. Retrieved on 24/06/2021 from https://siecon3607788.c.cdn77.org/sites/siecon.org/files/media_wysiwyg/288-manfre

McCarthy, Y. (2011). Behavioral characteristics and financial distress. European Central Bank. https://www.ecb.europa.eu/pub/pdf/scpwps/ecbwp1303.pdf?4ca9f70deb4b072c540 15aa30aac835b

Mian, A., Rao, K., \& Sufi, A. (2013). Household balance sheets, consumption, and the economic slump. The Quarterly Journal of Economics, 128(4), 1687-1726.

Mills, M., Blossfeld, H. P. \& Klijzing, E. (2005). Becoming an adult in uncertain times: A 14country comparison of the losers of globalization, pp. 393-411, In: H.-P. Blossfeld, E. Klijzing, M. Mills \& K. Kurz (Eds.) Globalization, Uncertainty and Youth in Society. London: Routledge Advances in Sociology Series.

Mitchell, O. S., Mottola, G. R., Utkus, S. P., \& Yamaguchi, T. (2006). The inattentive participant: Portfolio trading behavior in 401 (k) plans. Michigan Retirement Research Center Research Paper No.

Mudzingiri, C., Mwamba, M. J. W., \& Keyser, J. N. (2018). Financial behavior, confidence, risk preferences and financial literacy of university students. Cogent Economics \& Finance, 6(1), 1512366.

Narayan, D., R. Patel, K. Schafft, A. Rademacher, \& S. Koch-Schulte. (2000). Voices of the poor: Can anyone hear us? New York: World Bank, Oxford University Press.

O'Connor, G. E., Newmeyer, C. E., Wong, N. Y. C., Bayuk, J. B., Cook, L. A., Komarova, Y., ... Warmath, D. (2019). Conceptualizing the multiple dimensions of consumer financial vulnerability, Journal of Business Research, 100, 421-430.

O’Neill, B., Sorhaindo, B., Xiao, J. J., \& Garman, E. T. (2005). Financial distressed consumers: Their financial practices, financial well-being, and health. Financial Counseling and Planning, 16, 73-87.

Outlook, O. E. (2020). December 2020. Organization for Economic Cooperation and Development, 7.

Parrotta, J. L., \& Johnson, P. J. (1998). The impact of financial attitudes and knowledge on financial management and satisfaction of recently married individuals. Journal of Financial Counseling and Planning, 9(2), 59-75.

Pearlin, L. I., \& Bierman, A. (2013). Current issues and future directions in research into the stress process. In Handbook of the sociology of mental health (pp. 325-340). Springer, Dordrecht.

Poh, L. M., \& Sabri, M. F. (2017). Review of financial vulnerability studies. Archives of Business Research, 5(2), 127-134.

Rabbani, A., Yao, Z., Wang, C., \& John, G. (2019). Association between financial risk tolerance and locus of control, sensation seeking for pre-retiree baby boomers. Academic Research Colloquium for Financial Planning and Related Disciplines, 1-14. http://dx.doi.org/10.2139/ssrn.3256035.

Rea, J. K., Danes, S. M., Serido, J., Borden, L. M., and Shim, S. (2019). Being able to support yourself: Young adults' meaning of financial well-being through family financial socialization. Journal of Family and Economic Issues, 40, 250-268.

Reich, J. W., \& Zautra, A. J. (1983). Demands and desires in daily life: Some influences on wellbeing. American Journal of Community Psychology, 11(1), 41-58. http://dx.doi.org/10.1007/BF00898418 
Rotter, J. B. (1966). Generalized expectancies for internal versus external control of reinforcement. Psychological Monographs, 80, 1-28. http://dx.doi.org/ $10.1037 / \mathrm{h} 0092976$

Sabri, M. F., \& Wijekoon, R. (2019). The influence of gender and ethnicity on young adults' participation in financial education programme. Journal of Management and Sustainability, 9(1), 159-170. http://dx.doi.org/10. 5539/ jms. v9n1p159.

Sabri, M. F., MacDonald, M., Hira, T. K., \& Masud, J. (2010). Childhood consumer experience and the financial literacy of college students in Malaysia. Family \& Consumer Sciences Research Journal, 38(4), 455- 467

Sabri, M. F., Rahim, H. A., Wijekoon, R., Zakaria, N. F., Magli, A. S., \& Reza, T. S. (2020b). The mediating effect of money attitude on association between financial literacy, financial behavior, and financial vulnerability. International Journal of Academic Research in Business and Social Sciences, 10(15), 340-358.

http://dx.doi.org/10.6007/IJARBSS/v10-i15/8254

Sabri, M. F., Reza, T. S., \& Wijekoon, R. (2020a). Financial management, savings and investment behavior and financial well-being of working women in the public sector. Majalah IImiah Bijak, 17(2), 135-153.

Sabri, M. F., Wijekoon, R., Ramli, N. N., \& Dass, T. M. (2019). The impact of smart money kit on children's financial knowledge, attitude and behavior. Journal of Social Sciences and Humanities, 3, 48-59.

Sadiq, N., \& Ishaq, H. M. M. (2014). The Effect of Demographic Factors on the Behavior of Investors during the Choice of Investments: Evidence from Twin Cities of Pakistan. Global Journal of Management and Business Research, 14(3), 47-56.

Salisbury, L. C., \& Zhao, M. (2020). Active choice format and minimum payment warnings in credit card repayment decisions. Journal of Public Policy \& Marketing, 39(3), 284-304.

Serido, J., \& Deenanath, V. (2016). Financial parenting: Promoting fnancial self-reliance of young consumers. In J. J. Xiao (Ed.), Handbook of consumer finance research $\left(2^{\text {nd }} \mathrm{ed}\right.$., pp. 291-300). New York: Springer Science + Business Media. https://doi. org/10.1007/978-3-319-28887-1_24.

Spector, P. E., Cooper, C. L., Sanchez, J. I., O’Driscoll, M., Sparks, K., Bernin, P., ... \& Miller, K. (2002). Locus of control and well-being at work: How generalize are western findings? Academy of Management Journal, 45(2), 453-466.

Stromback, C., Lind, T., Skagerlund, K., Vastfjall, D., \& Tinghog, G. (2017). Does self-control predict financial behavior and financial well-being? Journal of Behavioral and Experimental Finance, 14, 30-38

Sumarwan, U., \& Hira, T. K. (1993). The effects of perceived locus of control and perceived income adequacy on satisfaction with financial status of rural households. Journal of Family and Economic Issues, 14, 343-364.

U.S. Census Bureau. (2013). American Community Survey, 2009- 2013 and decennial census 1980, 1990, 2000.

http://www.census.gov/content/dam/Census/newsroom/cspan/2015/20150130_cspa n_ younga dults.pdf

Van Daalen, H. J., Van Niekerk, E. C. \& Pottas, C. D. (1989). The validation of Furnham's locus of control scale for Black Southern African Group. Journal of Industrial Psychology, 15(1): 12-21.

Van de Venter, G., Michayluk, D., \& Davey, G. (2012). A longitudinal study of financial risk tolerance. Journal of Economic Psychology, 33(4), 794-800. 
Van den Brande, W., Baillien, E., De Witte, H., Vander Elst, T., \& Godderis, L. (2016). The role of work stressors, coping strategies and coping resources in the process of workplace bullying: a systematic review and development of a comprehensive model. Aggression and Violent Behavior, 29, 61-71. http://dx.doi.org/ 10.1016/j.avb. 2016.06.004.

Weisz, J. R., Rothbaum, F. M., \& Blackburn, T. C. (1984). Standing out and standing in: The psychology of control in America and Japan. American psychologist, 39(9), 955-969.

Worthington, A. C. (2006). Debt as a source of financial stress in Australian households. International Journal of Consumer Studies, 30,2-15. http://dx.doi.org/10.1111/ ijc.2006.30.issue-1.

Xiao, J. J. (2008). Applying behavior theories to financial behavior. In: Handbook of consumer finance research (pp. 69-81). Springer, New York, NY.

Xiao, J. J. (2009). Applying behavior theories to financial behavior. In Handbook of consumer finance research (pp. 69-81). New York: Springer.

Xiao, J. J., Ahn, S. Y., Serido, J., \& Shim, S. (2014). Earlier financial literacy and later financial behavior of college students. International Journal of Consumer Studies, 38(6), 593-601. http://dx.doi.org/ 10.1111/ijcs.12122.

Zaimah, R. (2011). Pengaruh pengetahuan, tingkahlaku dan pembuatan keputusan kewangan ke ataskesejahteraan kewangan pekerja sektor awam yang berkahwin (Unpublished doctoral dissertation), Universiti Putra Malaysia, Serdang. 